\title{
DEVELOPMENT AND VALIDATION OF ULTRAVIOLET SPECTROPHOTOMETRIC METHOD FOR DETERMINATION OF MEBHYDROLIN NAPADISYLATE IN TABLET PREPARATIONS
}

\author{
NERDY* \\ Department of Pharmacy, Academy of Pharmacy Yayasan Tenaga Pembangunan Arjuna, Pintubosi, Laguboti, Toba Samosir, Sumatera \\ Utara, 22381, Indonesia. Email: nerdy190690@gmail.com
}

Received: 31 December 2016, Revised and Accepted: 17 January 2017

\begin{abstract}
Objective: Mebhydrolin napadisylate is classified as an antihistamine drug classes used to treat allergies. One of the quality requirements for drug preparation was active compound levels must meet the requirements as stated in the Pharmacopeia or other standard books. The purpose of this study was to validate an ultraviolet spectrophotometric method for the determination of mebhydrolin napadisylate in the tablet preparation available in the market.
\end{abstract}

Methods: Solvents used are hydrochloric acid $0.1 \mathrm{~N}$ in methanol and sodium hydroxide $0.1 \mathrm{~N}$ in methanol for determination of mebhydrolin napadisylate and has not been reported. The ultraviolet spectrophotometric method used in the determination of mebhydrolin napadisylate will be conducted validation which includes accuracy, precision, linearity, range, limit of detection (LOD), and limit of quantitation (LOQ).

Results: Measurements were made at a maximum wavelength $\left(\lambda_{\max }\right)$ of mebhydrolin napadisylate $287 \mathrm{~nm}$. Results of ultraviolet spectrophotometric method validation in determination of mebhydrolin napadisylate in tablet preparation; accuracy, precision, linearity, range, LOD, and LOQ meet the requirements of validation tests for methods of analysis. The obtained results of the determination of mebhydrolin napadisylate levels in tablet preparation with a branded name on the market meet the general requirements of tablet preparation.

Conclusion: Ultraviolet spectrophotometric method of mebhydrolin napadisylate determination in tablet preparation meets the requirements of validation tests for methods of analysis. The determination of mebhydrolin napadisylate levels in tablet preparation meets the general requirements of tablet preparation.

Keywords: Development, Validation, Ultraviolet spectrophotometric, Mebhydrolin napadisylate.

(C) 2017 The Authors. Published by Innovare Academic Sciences Pvt Ltd. This is an open access article under the CC BY license (http://creativecommons. org/licenses/by/4. 0/) DOI: http://dx.doi.org/10.22159/ajpcr.2017.v10i4.16879

\section{INTRODUCTION}

Mebhydrolin napadisylate is the first generation of an antihistamine which is useful for treating allergies, which works to inhibit the central nervous system. Antihistamines comprise a broad class of pharmacological agents that include the first generation, relatively sedating $\mathrm{H}_{1}$ antagonists and second generation, less sedating or nonsedating $\mathrm{H}_{1}$ antagonists [1]. In the manufacture of pharmaceuticals, examination of the active substance level is a requirement that must be met to ensure the quality of drug preparations. Good quality medicine, which will support the achievement of the expected therapeutic effect. One of the level of quality requirements contained levels must meet the requirements as stated in the Pharmacopeia or other standard books [2]. Mebhydrolin napadisylate monograph not stated in the Indonesian Pharmacopeia, so the level requirements used in mebhydrolin napadisylate tablet preparations are general level requirements that contain active compounds not less than $90.0 \%$ and not more than $100.0 \%$ of the amount stated on the label.

Based from the structure, mebhydrolin napadisylate having a chromophore group and auxochrome group [3]. Compounds which have a chromophore group can absorb radiation in the ultraviolet region [4-6]. According to Dibbern et al., 2004, mebhydrolin napadisylate provides maximum absorbance in aqueous acid solvent at a wavelength of $286 \mathrm{~nm}\left(A_{1}^{1}=269\right)$ and in aqueous base solvent at a wavelength of $287 \mathrm{~nm}\left(A_{1}^{1}=274\right)$, so that the mebhydrolin napadisylate levels in tablet preparation can be determined by the ultraviolet spectrophotometric method [7]. Structure of mebhydrolin napadisylate can be seen in Fig. 1.

Determination of mebhydrolin napadisylate has ever done by densitometric method [8], high performance liquid chromatography method [9], and visible spectrophotometric method [10] and also has been validated the methods of analysis. However, the development and validation of ultraviolet spectrophotometric methods for determination of mebhydrolin napadisylate in tablet preparations have not been reported. Development of ultraviolet spectrophotometric methods is required because the method is simple, cheap, and fast [11].

The analytical method used for raw materials or active pharmaceutical substances should be able to provide results that can be replicated and reliably and to obtain the method used should be validated. Several parameter validation should be done, among others, the accuracy, precision, linearity, range, specificity, limit of detection (LOD), limit of quantitation (LOQ), ruggedness, and robustness [12]. Hence, the researchers are interested in determining the validity of the ultraviolet spectrophotometric method for determination of mebhydrolin napadisylate in tablet preparation using water, methanol, hydrochloric acid $(\mathrm{HCl}) 0.1 \mathrm{~N}$ in water, sodium hydroxide $(\mathrm{NaOH}) 0.1 \mathrm{~N}$ in water, $\mathrm{HCl} 0.1 \mathrm{~N}$ in methanol, and $\mathrm{NaOH} 0.1 \mathrm{~N}$ in methanol as the solvent. The method is validated with the parameters of accuracy, precision, linearity, range, LOD, and LOQ. Furthermore, the validated method is used to determine the levels of mebhydrolin napadisylate in tablet preparation on the market.

\section{METHODS}

This research is a descriptive study that aims to determine the validity of the ultraviolet spectrophotometric method for the determination of mebhydrolin napadisylate in tablet preparation marketed in Medan City, North Sumatera Province, Indonesia, whether it meets the general level requirements that contain active compounds not less than $90.0 \%$ and not more than $100.0 \%$ of the amount stated on the label. 


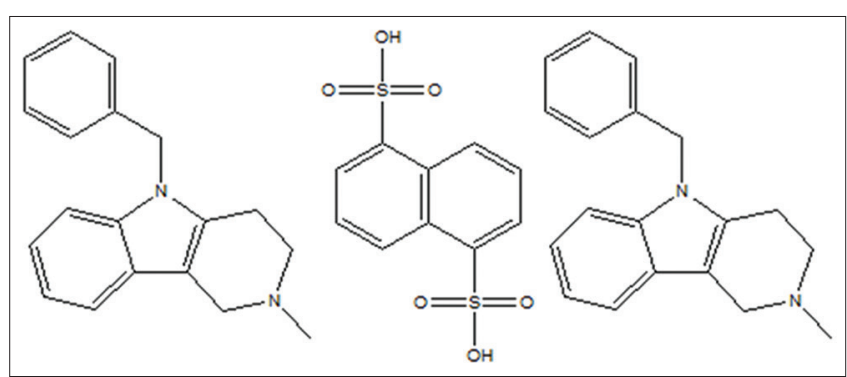

Fig. 1: Structure of mebhydrolin napadisylate

\section{Tools}

The tools used in the research were ultraviolet/visible spectrophotometer (Agilent), analytical balance (Boeco), and glassware (Iwaki).

\section{Materials}

The materials used in the research were $\mathrm{HCl}, \mathrm{NaOH}$, methanol $\left(\mathrm{CH}_{3} \mathrm{OH}\right)$, mebhydrolin napadisylate reference standard, mebhydrolin napadisylate $50 \mathrm{mg}$ tablets preparation with the branded name Histapan $^{\circledR}$ (PT. Sanbe), Gabiten ${ }^{\circledR}$ (PT. Ifars), Zoline ${ }^{\circledR}$ (PT. Pyridam), Interhistine ${ }^{\circledR}$ (PT. Interbat), Omecidal ${ }^{\circledR}$ (PT. Mutifa).

\section{Preparation of solvents}

\section{$\mathrm{HCl} 0.1 \mathrm{~N}$ in methanol}

A carefully measured amount of $8.5 \mathrm{ml}$ of $\mathrm{HCl}$, and then diluted in methanol to $1000 \mathrm{ml}$ [13].

\section{$\mathrm{NaOH} 0.1 \mathrm{~N}$ in methanol}

A carefully weighed amount of $4.0 \mathrm{~g}$ of $\mathrm{NaOH}$, and then dissolved in methanol to $1000 \mathrm{ml}$ [13].

\section{Preparation of stock solution (SS)}

Mebhydrolin napadisylate reference standard was weighed carefully the amount of $50.0 \mathrm{mg}$, put in a $100.0 \mathrm{ml}$ volumetric flask, added $60.0 \mathrm{ml}$ solvent, shaken until mebhydrolin napadisylate dissolved, diluted with a solvent to mark lines, shaken until homogeneous, obtained the mixture with a concentration of mebhydrolin napadisylate $500.00 \mu \mathrm{g} / \mathrm{mL}$, this solution is called SS I. The SS I pipetted amount of $15.0 \mathrm{ml}$, put in a $200.0 \mathrm{ml}$ volumetric flask, diluted with a solvent to mark lines, shaken until homogeneous, obtained the solution with a concentration of mebhydrolin napadisylate $37.50 \mu \mathrm{g} / \mathrm{mL}$, this solution is called SS II.

\section{Determination maximum absorbance $\left(A_{\max }\right)$ and maximum} wavelength $\left(\lambda_{\max }\right)$

The SS II pipetted amount of $4.0 \mathrm{ml}$, put in a $10.0 \mathrm{ml}$ volumetric flask, diluted with a solvent to mark lines, shaken until homogeneous, obtained the solution with a concentration of mebhydrolin napadisylate $15.00 \mu \mathrm{g} / \mathrm{mL}$, then measured the absorbance of the solution at the wavelength range of $200 \mathrm{~nm}$ to $400 \mathrm{~nm}$. A solvent used as a blank, then the specified maximum absorbance $\left(\mathrm{A}_{\max }\right)$ and the maximum wavelength $\left(\lambda_{\max }\right)[14]$.

\section{Determination of linearity, LOD, and LOQ}

The SS II pipetted amount of 2.0, 3.0, 4.0, 5.0, and $6.0 \mathrm{ml}$, each put in a $10.0 \mathrm{ml}$ volumetric flask, each diluted with a solvent to mark lines, each shaken until homogeneous, obtained the solution with a concentration of mebhydrolin napadisylate, respectively, 7.50, 11.25, $15.00,18.75$, and $22.50 \mu \mathrm{g} / \mathrm{mL}$, then measured the absorbance of the solution at maximum wavelength $\left(\lambda_{\max }\right)$ obtained. A solvent used as a blank, then calculated the coefficient of correlation (r), coefficient of determination $\left(r^{2}\right)$, regression line equation, LOD, and LOQ [15].

$$
\mathrm{a}=\frac{\sum \mathrm{XY}-\left(\sum \mathrm{X}\right) \times\left(\sum \mathrm{Y}\right) / \mathrm{n}}{\sum \mathrm{X}^{2}-\left(\sum \mathrm{X}\right)^{2} / \mathrm{n}}
$$

$$
\begin{aligned}
& \mathrm{b}=\overline{\mathrm{Y}}-\mathrm{a} \times \overline{\mathrm{X}} \\
& \mathrm{r}=\frac{\left(\sum \mathrm{XY}\right)-\left(\sum \mathrm{X}\right) \times\left(\sum \mathrm{Y}\right) / \mathrm{n}}{\sqrt{\left[\left(\sum \mathrm{X}\right)^{2}-\left(\sum \mathrm{X}\right)^{2} / \mathrm{n}\right]\left[\left(\sum \mathrm{Y}\right)^{2}-\left(\sum \mathrm{Y}\right)^{2} / \mathrm{n}\right]}} \\
& \mathrm{r}^{2}=\left(\frac{\left(\sum \mathrm{XY}\right)-\left(\sum \mathrm{X}\right) \times\left(\sum \mathrm{Y}\right) / \mathrm{n}}{\sqrt{\left[\left(\sum \mathrm{X}\right)^{2}-\left(\sum \mathrm{X}\right)^{2} / \mathrm{n}\right]\left[\left(\sum \mathrm{Y}\right)^{2}-\left(\sum \mathrm{Y}\right)^{2} / \mathrm{n}\right]}}\right)^{2}
\end{aligned}
$$$$
S Y / X=\sqrt{\frac{\sum(Y-Y i)}{n-2}}
$$$$
\mathrm{LOD}=\frac{3 \times \mathrm{S} Y / \mathrm{X}}{\mathrm{a}}
$$$$
\mathrm{LOQ}=\frac{10 \times \mathrm{S} Y / \mathrm{X}}{\mathrm{a}}
$$

Note:

$\mathrm{Y}=$ Measurement absorbance,

$\mathrm{Yi}=$ Calculated absorbance,

$\mathrm{X}=$ Concentration,

$\mathrm{n}=$ Number of treatments,

$\mathrm{a}=$ Slope,

$\mathrm{b}=$ Intercept,

$\mathrm{r}=$ Coefficient of correlation,

$\mathrm{r}^{2}=$ Coefficient of determination,

$\mathrm{S}_{\mathrm{Y}}^{\mathrm{Y}} \mathrm{x}=$ Residual standard deviation,

LOD=Limit of detection,

LOQ=Limit of quantitation.

Determination of mebhydrolin napadisylate levels in tablet preparation

Not $<20$ tablets were weighed and powdered, weighed carefully the amount of powder equivalent to $50.0 \mathrm{mg}$ mebhydrolin napadisylate (weighing powders as much as 6 times repetition), put in a $100.0 \mathrm{ml}$ volumetric flask, added $60.0 \mathrm{ml}$ solvent, shaken until mebhydrolin napadisylate dissolved, diluted with a solvent to mark lines, shaken until homogeneous, obtained the mixture with a concentration of mebhydrolin napadisylate $500.00 \mu \mathrm{g} / \mathrm{mL}$. The mixture was filtered through a funnel and filter paper, removed $20 \mathrm{ml}$ of the first filtrate was, accommodated the later filtrate, discarded residue, pipetted amount of $15.0 \mathrm{ml}$ filtrate, put in a $200.0 \mathrm{ml}$ volumetric flask, diluted with a solvent to mark lines, shaken until homogeneous, obtained the solution with a concentration of mebhydrolin napadisylate $37.50 \mu \mathrm{g} / \mathrm{mL}$. The solution was pipetted amount of $4.0 \mathrm{ml}$, put in a $10.0 \mathrm{ml}$ volumetric flask, diluted with a solvent to mark lines, shaken until homogeneous, obtained the solution with a concentration of mebhydrolin napadisylate $15.00 \mu \mathrm{g} / \mathrm{mL}$, then measured the absorbance of the solution at maximum wavelength $\left(\lambda_{\max }\right)$ obtained. A solvent used as a blank, then calculated the concentration mebhydrolin napadisylate in the sample solution using the regression line equation, and the calculated levels of mebhydrolin napadisylate in tablet preparation. Calculated the standard deviation (SD), determination of the data received or rejected using the calculated T value $\left(\mathrm{T}_{\text {calc }}\right)$, determination of actual level $(\mu)$ of the analyte with confidence level $99 \%$, and degree of freedom.

$\mathrm{SD}=\sqrt{\frac{\sum(\mathrm{X}-\overline{\mathrm{X}})^{2}}{\mathrm{n}-1}}$

$\mathrm{T}_{\text {calc }}=\frac{|\mathrm{X}-\overline{\mathrm{X}}|}{\mathrm{SD} / \sqrt{\mathrm{n}}}$ 


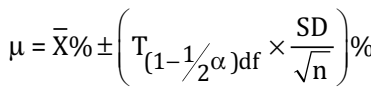

$\mathrm{df}=\mathrm{n}-1$

Note:

$\overline{\mathrm{X}}=$ Average levels of sample,

$\mathrm{n}=$ Number of treatments,

$\mathrm{T}_{\text {calc }}=$ Calculated $\mathrm{T}$ value,

$\mathrm{SD}=$ Standard deviation

$\mu=$ Actual level,

$\mathrm{T}=$ Table $\mathrm{T}$ value

$\mathrm{df}=$ Degree of freedom,

$\alpha=$ Confidence level

\section{Determination of accuracy and precision}

Accuracy test and precision test conducted on mebhydrolin napadisylate tablet samples in tablet preparation under the branded name Zoline ${ }^{\circledR}$ (PT. Pyridam). Accuracy test conducted by standard addition method to create a specific range of analyte concentrations with $80.00 \%, 100.00 \%$, and $120.00 \%$ calculated from the amount of mebhydrolin napadisylate stated on the label, each specific range performed 3 times repetition. Each specific range containing $70 \%$ of samples and $30 \%$ of reference standards, then analyzed with the same treatment as the sample assay. Determination of the accuracy of the analysis method is determined by calculation of recovery percentage (\% Recovery) after addition of the mebhydrolin napadisylate reference standard in the mebhydrolin napadisylate tablet sample [16]. Precision test is done by calculating the relative SD (RSD) of the percentage of the recovery percentage (\% Recovery) that has been obtained from the accuracy test [17].

$\%$ Recovery $=\frac{A-B}{C} \times 100 \%$

$\mathrm{RSD}=\frac{\mathrm{SD}}{\overline{\mathrm{X}}} \times 100 \%$

Note:

$\%$ Recovery=Recovery percentage,

$A=$ Analyte mass after the standard addition,

$\mathrm{B}=$ Analyte mass before the standard addition,

$\mathrm{C}=$ Standard added,

RSD=Relative standard deviation,

$\mathrm{SD}=$ Standard deviation,

$\overline{\mathrm{X}}=$ Average of recovery percentage.

\section{RESULTS AND DISCUSSIONS}

According to Dibbern et al., 2004, mebhydrolin napadisylate has a maximum absorbance spectrum in the ultraviolet region in an acid solution at a wavelength of $286 \mathrm{~nm}\left(A_{1}^{1}=269\right)$ and in a base solution at a wavelength of $287 \mathrm{~nm}\left(A_{1}^{1}=274\right)$. Previously, researchers done orientation of determination of mebhydrolin napadisylate with several solvents, using water, methanol, $\mathrm{HCl} 0.1 \mathrm{~N}$ in water, $\mathrm{NaOH} 0.1 \mathrm{~N}$ in water, $\mathrm{HCl} 0.1 \mathrm{~N}$ in methanol, and $\mathrm{NaOH} 0.1 \mathrm{~N}$ in methanol. However, mebhydrolin napadisylate not completely soluble in water, methanol, $\mathrm{HCl} 0.1 \mathrm{~N}$ in water, and $\mathrm{NaOH} 0.1 \mathrm{~N}$ water. Using $\mathrm{HCl}, 0.1 \mathrm{~N}$ in methanol and $\mathrm{NaOH} 0.1 \mathrm{~N}$ in methanol as a solvent, it turns out mebhydrolin napadisylate dissolve completely, so the researchers used $\mathrm{HCl} 0.1 \mathrm{~N}$ in methanol and $\mathrm{NaOH} 0.1 \mathrm{~N}$ in methanol as solvent in this research.

Determination maximum absorbance $\left(A_{\max }\right)$ and maximum wavelength $\left(\lambda_{\max }\right)$

Determination of mebhydrolin napadisylate in tablet preparation, beginning with the determination of the maximum wavelength even though the maximum wavelength $\left(\lambda_{\max }\right)$ is already known from literature for the maximum wavelength $\left(\lambda_{\max }\right)$ of a compound can differ when determined by the different conditions (solvent) and tools. Determination of the wavelength is performed in the solvent $\mathrm{HCl} 0.1 \mathrm{~N}$ in methanol and in the solvent $\mathrm{NaOH} 0.1 \mathrm{~N}$ in methanol at a concentration that gives absorbance with the smallest photometric error, which is \pm 0 .4. Determination of the maximum wavelength with a concentration of $15 \mu \mathrm{g} / \mathrm{mL}$ which provides absorbance approaching 0.4 . Absorbance spectrum and absorbance spectrum data of mebhydrolin napadisylate in the solvent $\mathrm{HCl} 0.1 \mathrm{~N}$ in methanol and in the solvent $\mathrm{NaOH} 0.1 \mathrm{~N}$ in methanol can be seen in Fig. 2 and Table 1.

Mebhydrolin napadisylate absorbance spectrum in the solvent $\mathrm{HCl} 0.1 \mathrm{~N}$ in methanol and in the solvent $\mathrm{NaOH} 0.1 \mathrm{~N}$ in methanol showed only one peak. Maximum absorbance $\left(A_{\text {max }}\right)$ and maximum wavelength $\left(\lambda_{\text {max }}\right)$ of mebhydrolin napadisylate show that the maximum absorbance $\left(A_{\max }\right)$ of mebhydrolin napadisylate in the solvent $\mathrm{HCl} 0.1 \mathrm{~N}$ in methanol is 0.40557 with the maximum wavelength $\left(\lambda_{\max }\right) 287 \mathrm{~nm}$ and maximum absorbance $\left(\mathrm{A}_{\max }\right)$ of mebhydrolin napadisylate in the solvent $\mathrm{NaOH}$ $0.1 \mathrm{~N}$ in methanol is 0.41223 with the maximum wavelength $\left(\lambda_{\max }\right)$ $287 \mathrm{~nm}$. Maximum wavelength $\left(\lambda_{\text {max }}\right)$ obtained from measurements similar to the maximum wavelength $\left(\lambda_{\max }\right)$ obtained from literature $(287 \mathrm{~nm})$ in the base solvent, but maximum wavelength $\left(\lambda_{\max }\right)$ obtained from measurements different $1 \mathrm{~nm}$ compared to the maximum wavelength $\left(\lambda_{\mathrm{mat}}\right)$ obtained from literature $(286 \mathrm{~nm})$ in the acid solvent. This result is still in the allowed range, the maximum wavelength $\left(\lambda_{\max }\right)$ difference between the measurement results and the literature is not more than $2 \mathrm{~nm}$ [18]. Furthermore, determination of mebhydrolin napadisylate in tablet preparation on the market is done at a maximum wavelength $\left(\lambda_{\max }\right)$ obtained.

\section{Determination of linearity, LOD, and LOQ}

Linearity determination of the mebhydrolin napadisylate calibration curve is done with the concentration range of $7.5-22.5 \mu \mathrm{g} / \mathrm{mL}$ at a wavelength of $287 \mathrm{~nm}$ using $\mathrm{HCl} 0.1 \mathrm{~N}$ in methanol and $\mathrm{NaOH} 0.1 \mathrm{~N}$ in methanol as a solvent and a blank. The curve calibration and calibration curve data of mebhydrolin napadisylate in the solvent $\mathrm{HCl} 0.1 \mathrm{~N}$ in methanol and in the solvent $\mathrm{NaOH} 0.1 \mathrm{~N}$ in methanol can be seen in Fig. 3 and Table 2.

The results of the mebhydrolin napadisylate calibration curve measurements in the solvent $\mathrm{HCl} 0.1 \mathrm{~N}$ in methanol with the concentration range of $7.5-22.5 \mu \mathrm{g} / \mathrm{mL}$ at a wavelength of $287 \mathrm{~nm}$ obtained linear

Table 1: Absorbance spectrum data of mebhydrolin napadisylate absorbance spectrum (concentration of $15 \mu \mathrm{g} / \mathrm{mL}$ ) in the solvent $\mathrm{HCl} 0.1 \mathrm{~N}$ in methanol and in the solvent $\mathrm{NaOH} 0.1 \mathrm{~N}$ in methanol

\begin{tabular}{llll}
\hline S.No. & Wavelength & Absorbance & Solvent \\
\hline 1 & $287 \mathrm{~nm}$ & 0.40577 & HCl 0.1 N in methanol \\
2 & $287 \mathrm{~nm}$ & 0.41223 & NaOH 0.1 N in methanol \\
\hline
\end{tabular}

$\mathrm{HCl}$ : Hydrochloric acid, $\mathrm{NaOH}$ : Sodium hydroxide

Table 2: Calibration curve data of mebhydrolin napadisylate in the solvent $\mathrm{HCl} 0.1 \mathrm{~N}$ in methanol and in the solvent $\mathrm{NaOH} 0.1 \mathrm{~N}$ in methanol

\begin{tabular}{|c|c|c|c|}
\hline \multirow[t]{2}{*}{ S.No } & \multirow[t]{2}{*}{ Concentration } & \multicolumn{2}{|l|}{ Absorbance } \\
\hline & & $\begin{array}{l}\mathrm{HCl} 0.1 \mathrm{~N} \text { in } \\
\text { methanol }\end{array}$ & $\begin{array}{l}\mathrm{NaOH} 0.1 \mathrm{~N} \text { in } \\
\text { methanol }\end{array}$ \\
\hline 1 & $0.00 \mu \mathrm{g} / \mathrm{mL}$ & 0.00000 & 0.00000 \\
\hline 2 & $7.50 \mu \mathrm{g} / \mathrm{mL}$ & 0.20289 & 0.20614 \\
\hline 3 & $11.25 \mu \mathrm{g} / \mathrm{mL}$ & 0.30432 & 0.30921 \\
\hline 4 & $15.00 \mu \mathrm{g} / \mathrm{mL}$ & 0.40579 & 0.41226 \\
\hline 5 & $18.75 \mu \mathrm{g} / \mathrm{mL}$ & 0.50731 & 0.51530 \\
\hline 6 & $22.50 \mu \mathrm{g} / \mathrm{mL}$ & 0.60873 & 0.61841 \\
\hline
\end{tabular}

$\mathrm{HCl}$ : Hydrochloric acid, $\mathrm{NaOH}$ : Sodium hydroxide 


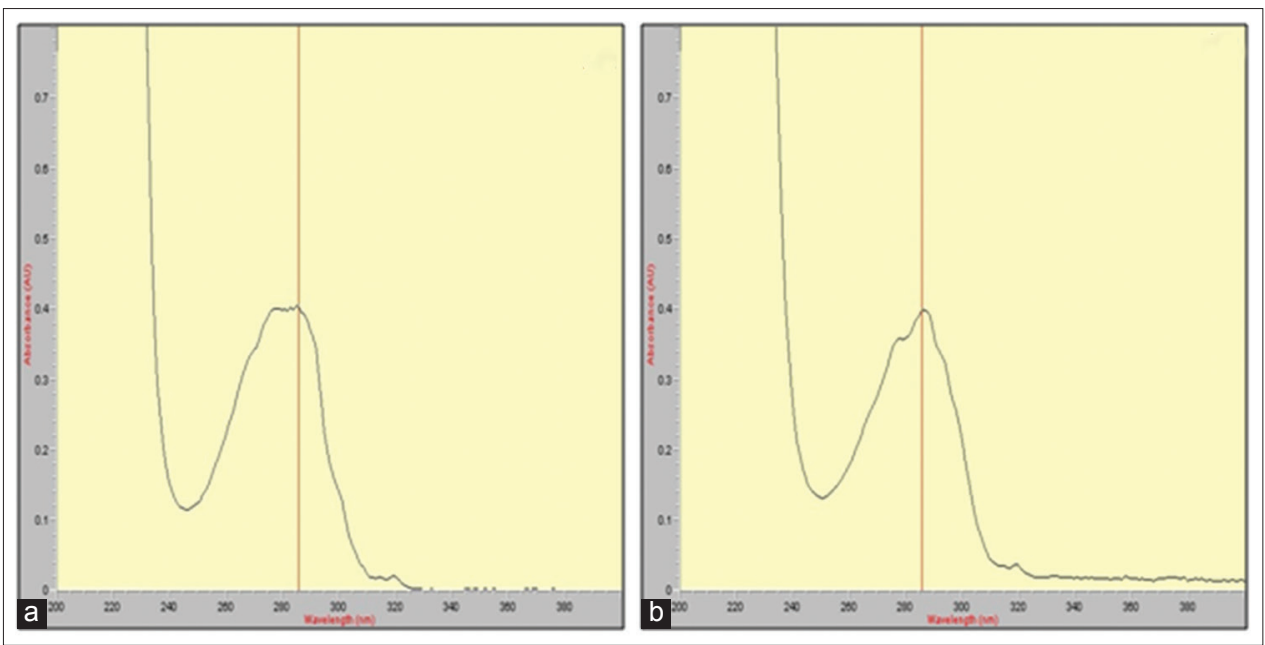

Fig. 2: Absorbance spectrum of mebhydrolin napadisylate (concentration of $15 \mu \mathrm{g} / \mathrm{mL}$ ) in the solvent hydrochloric acid $0.1 \mathrm{~N}$ in methanol (a) and in the solvent sodium hydroxide $0.1 \mathrm{~N}$ in methanol (b)
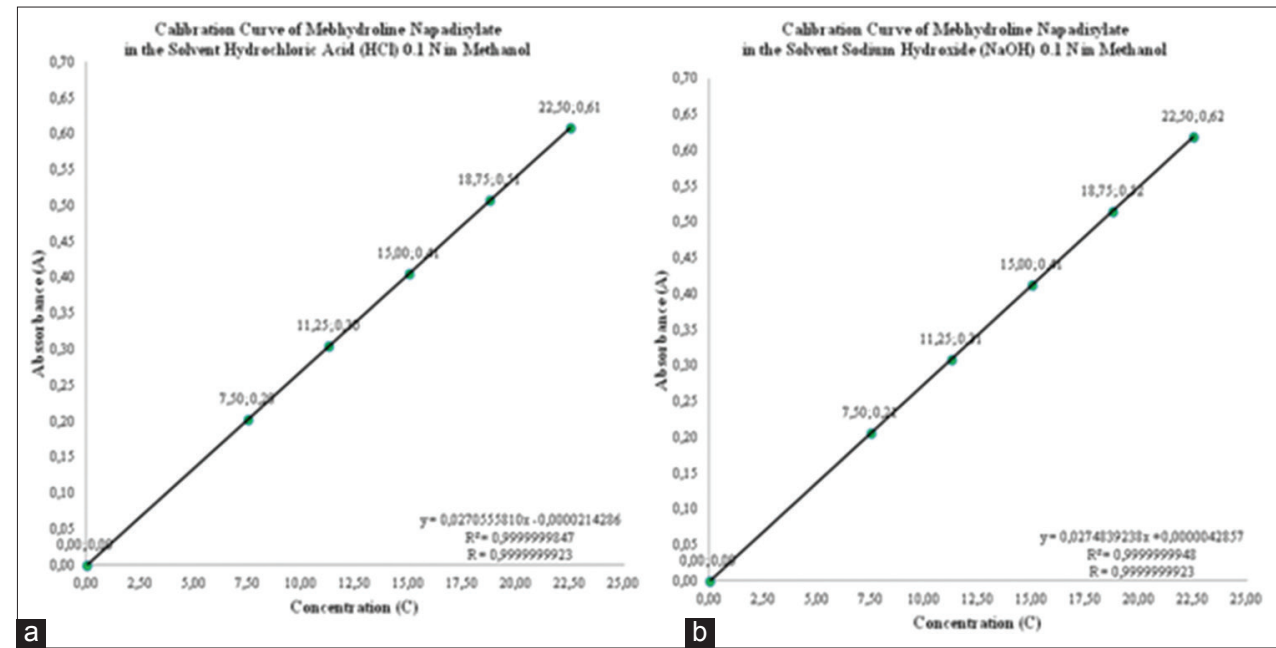

Fig. 3: Calibration curve of mebhydrolin napadisylate in the solvent hydrochloric acid $0.1 \mathrm{~N}$ in methanol (a) and in the solvent sodium hydroxide $0.1 \mathrm{~N}$ in methanol (b) at a wavelength of $287 \mathrm{~nm}$

relationship between concentration and absorbance with the coefficient of correlation $(\mathrm{r})=0.9999999923$ and the coefficient of determination $\left(\mathrm{r}^{2}\right)=0.9999999847$. The correlation coefficient obtained has met the requirements, the acceptance criteria for the correlation coefficient is $r \geq 0.995$ [3]. The calculation result of the regression line equation obtained the regression line equation $\mathrm{Y}=0.0272555810 \times \mathrm{X}-0.0000214286$. From the calibration curve, data can be calculated that determination of mebhydrolin napadisylate by an ultraviolet spectrophotometric method in the solvent $\mathrm{HCl} 0.1 \mathrm{~N}$ in methanol has the LOD of $0.0015 \mu \mathrm{g} / \mathrm{mL}$ and the $\mathrm{LOQ}$ of $0.0046 \mu \mathrm{g} / \mathrm{mL}$. All the measurement concentration must above the LOD and LOQ to meet the requirements of accuracy and precision [19]

The results of the mebhydrolin napadisylate calibration curve measurements in the solvent $\mathrm{NaOH} 0.1 \mathrm{~N}$ in methanol with the concentration range of $7.5-22.5 \mu \mathrm{g} / \mathrm{mL}$ at a wavelength of $287 \mathrm{~nm}$ obtained linear relationship between concentration and absorbance with the coefficient of correlation ( $r)=0.9999999974$ and the coefficient of determination $\left(\mathrm{r}^{2}\right)=0.9999999948$. The correlation coefficient obtained has met the requirements, the acceptance criteria for the correlation coefficient is $r \geq 0.995$ [3]. The calculation result of the regression line equation obtained the regression line equation $\mathrm{Y}=0.0274839238 \times \mathrm{X}+0.0000042857$. From the calibration curve, data can be calculated that the determination of mebhydrolin napadisylate by an ultraviolet spectrophotometric method in the solvent $\mathrm{NaOH} 0.1 \mathrm{~N}$ in methanol has the LOD of $0.0009 \mu \mathrm{g} / \mathrm{mL}$ and the LOQ of $0.0027 \mu \mathrm{g} / \mathrm{mL}$. All the measurement concentrations must above the LOD and LOQ to meet the requirements of accuracy and precision [19].

Determination of mebhydrolin napadisylate levels in tablet preparation

Determination of mebhydrolin napadisylate in a tablet preparation results and recapitulation of mebhydrolin napadisylate levels to determine the mebhydrolin napadisylate level in Histapan ${ }^{\circledR}$ (PT. Sanbe), Gabiten ${ }^{\circledR}$ (PT. Ifars), Zoline ${ }^{\circledR}$ (PT. Pyridam), Interhistine ${ }^{\circledR}$ (PT. Interbat), and Omecidal ${ }^{\circledR}$ (PT. Mutifa) in the solvent $\mathrm{HCl} 0.1 \mathrm{~N}$ in methanol and in the solvent $\mathrm{NaOH} 0.1 \mathrm{~N}$ in methanol can be seen, respectively, in Tables 3 and 4 .

Determination of mebhydrolin napadisylate results showed that the levels of mebhydrolin napadisylate in tablet preparation in the solvent $\mathrm{HCl} 0.1 \mathrm{~N}$ in methanol and in the solvent $\mathrm{NaOH} 0.1 \mathrm{~N}$ in methanol with a branded name on the market meet the general level requirements that contains active compounds not $<90.0 \%$ and not more than $100.0 \%$ of the amount stated on the label.

\section{Determination of range, accuracy and precision}

Accuracy test conducted by standard addition method on Zoline ${ }^{\circledR}$ (PT. Pyridam) samples tablets with recovery percentage (\% recovery) parameter. Precision test is done by calculating the RSD of the percentage 
of the recovery percentage (\% recovery) that has been obtained from the accuracy test. Accuracy test with recovery percentage (\% recovery) parameter is done by making three concentrations of the samples with a specific range $80.00 \%, 100.00 \%$, and $120.00 \%$ was calculated from the levels mebhydrolin napadisylate stated on the label, where each

Table 3: Mebhydrolin napadisylate level in tablet preparation results in the solvent $\mathrm{HCl} 0.1 \mathrm{~N}$ in methano

\begin{tabular}{llll}
\hline $\begin{array}{l}\text { S. } \\
\text { No. }\end{array}$ & $\begin{array}{l}\text { Tablet preparation } \\
\text { branded name }\end{array}$ & $\begin{array}{l}\text { Average } \\
\text { level }(\overline{\mathbf{X}}) \\
(\%)\end{array}$ & $\begin{array}{l}\text { Actual } \\
\text { level }(\boldsymbol{\mu}) \mathbf{( \% )}\end{array}$ \\
\hline 1 & Histapan $^{\circledR}$ (PT. Sanbe) & 99.22 & $99.22 \pm 0.25$ \\
2 & Gabiten $^{\circledR}$ (PT. Ifars) & 98.98 & $98.98 \pm 0.38$ \\
3 & Zoline $^{\circledR}$ (PT. Pyridam) & 99.62 & $99.62 \pm 0.23$ \\
4 & Interhistine $^{\circledR}$ (PT. Interbat) & 99.44 & $99.44 \pm 0.30$ \\
5 & Omecidal $^{\circledR}$ (PT. Mutifa) & 99.52 & $99.52 \pm 0.20$ \\
\hline
\end{tabular}

HCl: Hydrochloric acid

Table 4: Mebhydrolin napadisylate level in tablet preparation results in the solvent $\mathrm{NaOH} 0.1 \mathrm{~N}$ in methanol

\begin{tabular}{llll}
\hline No & $\begin{array}{l}\text { Tablet preparation } \\
\text { branded name }\end{array}$ & $\begin{array}{l}\text { Average } \\
\text { level }(\overline{\mathbf{X}}) \\
\text { (\%) }\end{array}$ & $\begin{array}{l}\text { Actual } \\
\text { level }(\boldsymbol{\mu}) \mathbf{( \% )}\end{array}$ \\
\hline 1 & Histapan $^{\circledR}$ (PT. Sanbe) & 99.45 & $99.45 \pm 0.51$ \\
2 & Gabiten $^{\circledR}$ (PT. Ifars) & 98.39 & $98.39 \pm 0.22$ \\
3 & Zoline $^{\circledR}$ (PT. Pyridam) & 99.83 & $99.83 \pm 0.27$ \\
4 & Interhistine $^{\circledR}$ (PT. Interbat) & 99.57 & $99.57 \pm 0.44$ \\
5 & Omecidal $^{\circledR}$ (PT. Mutifa) & 99.67 & $99.67 \pm 0.37$ \\
\hline
\end{tabular}

$\mathrm{NaOH}$ : Sodium hydroxide specific range was done with three repetitions, and each specific range contains $70 \%$ of samples and $30 \%$ reference standards. Solvents used in accuracy test and precision test were $\mathrm{HCl} 0.1 \mathrm{~N}$ in methanol and $\mathrm{NaOH} 0.1 \mathrm{~N}$ in methanol. Tables 5 and 6 showed the accuracy test and precision test result data on ultraviolet spectrophotometric method for the determination of mebhydrolin napadisylate in tablet preparations in the solvent $\mathrm{HCl} 0.1 \mathrm{~N}$ in methanol and in the solvent $\mathrm{NaOH} 0.1 \mathrm{~N}$ in methanol with standard addition method.

Accuracy test result with recovery percentage (\% recovery) parameter in ultraviolet spectrophotometric method for determination of mebhydrolin napadisylate in tablet preparations in the solvent $\mathrm{HCl}$ $0.1 \mathrm{~N}$ in methanol and in the solvent $\mathrm{NaOH} 0.1 \mathrm{~N}$ in methanol with standard addition method obtained recovery percentage (\% recovery), respectively, $100.03 \%$ and $100.21 \%$. This accuracy result meets the accuracy requirements, where the value of the recovery percentage ( $\%$ recovery) is permitted between $98.0 \%$ and $102.0 \%$. Precision test result with RSD parameter in ultraviolet spectrophotometric method for determination of mebhydrolin napadisylate in tablet preparations in the solvent $\mathrm{HCl} 0.1 \mathrm{~N}$ in methanol and in the solvent $\mathrm{NaOH} 0.1 \mathrm{~N}$ in methanol with standard addition method obtained RSD, respectively, $0.03 \%$ and $0.18 \%$. This precision result meets the precision requirements, where the value of the RSD is permitted not more than $2 \%$ [16]. The lower concentration of accuracy test was $80.00 \%$ from the test concentration $(15.00 \mu \mathrm{g} / \mathrm{mL})$ and the higher concentration of accuracy test was $120.00 \%$ from the test concentration $(15.00 \mu \mathrm{g} / \mathrm{mL})$. The range obtained from the method validation was $12.00-18.00 \mu \mathrm{g} / \mathrm{mL}$ for both solvents.

\section{Method validation}

The validation test results of ultraviolet spectrophotometric method for determination of mebhydrolin napadisylate in tablet preparations

Table 5: Accuracy test and precision test result data on ultraviolet spectrophotometric method for determination of mebhydrolin napadisylate in tablet preparations in the solvent $\mathrm{HCl} 0.1 \mathrm{~N}$ in methanol with standard addition method

\begin{tabular}{|c|c|c|c|c|c|c|c|}
\hline \multirow[t]{2}{*}{ No } & \multirow[t]{2}{*}{ Specific range $(\%)$} & \multicolumn{2}{|l|}{ Absorbance } & \multicolumn{3}{|l|}{ Analyte mass (mg) } & \multirow{2}{*}{$\begin{array}{l}\text { Recovery } \\
\text { percentage }\end{array}$} \\
\hline & & $\begin{array}{l}\text { Before the standard } \\
\text { addition }\end{array}$ & $\begin{array}{l}\text { After the standard } \\
\text { addition }\end{array}$ & $\begin{array}{l}\text { Before the standard } \\
\text { addition }\end{array}$ & $\begin{array}{l}\text { After the standard } \\
\text { addition }\end{array}$ & $\begin{array}{l}\text { Standard } \\
\text { added }\end{array}$ & \\
\hline 1 & \multirow[t]{3}{*}{80.00} & 0.22751 & 0.32488 & 28.0326 & 40.0289 & \multirow[t]{3}{*}{11.98680} & 100.08 \\
\hline 2 & & 0.22797 & 0.32527 & 28.0893 & 40.0769 & & 100.01 \\
\hline 3 & & 0.22768 & 0.32497 & 28.0535 & 40.0400 & & 100.00 \\
\hline 4 & \multirow[t]{3}{*}{100.00} & 0.28487 & 0.40651 & 35.0995 & 50.0860 & \multirow[t]{3}{*}{14.98350} & 100.02 \\
\hline 5 & & 0.28446 & 0.40612 & 35.0490 & 50.0379 & & 100.04 \\
\hline 6 & & 0.28415 & 0.40588 & 35.0108 & 50.0083 & & 100.09 \\
\hline 7 & \multirow[t]{3}{*}{120.00} & 0.34105 & 0.48705 & 42.0211 & 60.0087 & \multirow[t]{3}{*}{17.98020} & 100.04 \\
\hline 8 & & 0.34144 & 0.48739 & 42.0691 & 60.0506 & & 100.01 \\
\hline 9 & & 0.34168 & 0.48765 & 42.0987 & 60.0827 & & 100.02 \\
\hline \multicolumn{7}{|c|}{ Average \% Recovery (\%) } & 100.03 \\
\hline \multicolumn{7}{|c|}{ RSD (\%) } & 0.03 \\
\hline
\end{tabular}

HCl: Hydrochloric acid, RSD: Relative standard deviation

Table 6: Accuracy test and precision test result data on ultraviolet spectrophotometric method for determination of mebhydrolin napadisylate in tablet preparations in the solvent $\mathrm{NaOH} 0.1 \mathrm{~N}$ in methanol with standard addition method

\begin{tabular}{|c|c|c|c|c|c|c|c|}
\hline \multirow[t]{2}{*}{ No } & \multirow[t]{2}{*}{ Specific range } & \multicolumn{2}{|l|}{ Absorbance } & \multicolumn{3}{|l|}{ Analyte mass (mg) } & \multirow{2}{*}{$\begin{array}{l}\text { Recovery } \\
\text { percentage }\end{array}$} \\
\hline & & $\begin{array}{l}\text { Before the standard } \\
\text { addition }\end{array}$ & $\begin{array}{l}\text { After the standard } \\
\text { addition }\end{array}$ & $\begin{array}{l}\text { Before the standard } \\
\text { addition }\end{array}$ & $\begin{array}{l}\text { After the standard } \\
\text { addition }\end{array}$ & $\begin{array}{l}\text { Standard } \\
\text { added }\end{array}$ & \\
\hline 2 & \multirow{2}{*}{$80.00 \%$} & 0.23094 & 0.33018 & 28.0086 & 40.0447 & \multirow{2}{*}{11.98680} & 100.41 \\
\hline 3 & & 0.23108 & 0.33002 & 28.0256 & 40.0253 & & 100.11 \\
\hline 4 & \multirow[t]{3}{*}{$100.00 \%$} & 0.28882 & 0.41291 & 35.0284 & 50.0785 & \multirow[t]{3}{*}{14.98350} & 100.44 \\
\hline 5 & & 0.28894 & 0.41247 & 35.0430 & 50.0251 & & 99.99 \\
\hline 6 & & 0.28887 & 0.41265 & 35.0345 & 50.0469 & & 100.19 \\
\hline 7 & \multirow[t]{3}{*}{$120.00 \%$} & 0.34612 & 0.49501 & 41.9780 & 60.0358 & \multirow[t]{3}{*}{17.98020} & 100.43 \\
\hline 8 & & 0.34635 & 0.49488 & 42.0059 & 60.0200 & & 100.19 \\
\hline 9 & & 0.34657 & 0.49475 & 42.0325 & 60.0043 & & 99.95 \\
\hline \multicolumn{7}{|c|}{ Average $\%$ recovery $(\%)$} & 100.21 \\
\hline \multicolumn{7}{|c|}{ RSD (\%) } & 0.18 \\
\hline
\end{tabular}

NaOH: Sodium hydroxide, RSD: Relative standard deviation 
in the solvent $\mathrm{HCl} 0.1 \mathrm{~N}$ in methanol and in the solvent $\mathrm{NaOH} 0.1 \mathrm{~N}$ in methanol with the test parameters: accuracy, precision, linearity, range, LOD, and LOQ showed that ultraviolet spectrophotometric method is valid for determination of mebhydrolin napadisylate in tablet preparations in the solvent $\mathrm{HCl} 0.1 \mathrm{~N}$ in methanol and in the solvent $\mathrm{NaOH} 0.1 \mathrm{~N}$ in methanol. Determination of mebhydrolin napadisylate has ever done by densitometric method [8], high performance liquid chromatography method [9], and visible spectrophotometric method [10] and also has been validated the methods of analysis. In this study, the researcher obtained the valid ultraviolet spectrophotometric method that is simpler, cheaper, and faster than previously validated methods (densitometric, high performance liquid chromatography, and visible spectrophotometric.

\section{CONCLUSIONS}

From the research, mebhydrolin napadisylate in tablet preparation can be determined using the ultraviolet spectrophotometric method using the solvent $\mathrm{HCl} 0.1 \mathrm{~N}$ in methanol and the solvent $\mathrm{NaOH} 0.1 \mathrm{~N}$ in methanol at a wavelength of $287 \mathrm{~nm}$. The results of the analysis method validation test with accuracy, precision, linearity, range, LOD, and LOQ meet the requirements. Mebhydrolin napadisylate assay showed that all the tablets analyzed with the branded name Histapan ${ }^{\circledR}$ (PT. Sanbe), Gabiten ${ }^{\circledR}$ (PT. Ifars), Zoline ${ }^{\circledR}$ (PT. Pyridam), Interhistine ${ }^{\circledR}$ (PT. Interbat), and Omecidal ${ }^{\circledR}$ (PT. Mutifa) meet the general level requirements that contain active compounds not $<90.0 \%$ and not more than $100.0 \%$ of the amount stated on the label.

\section{REFERENCES}

1. Criado PR, Criado RF, Maruta CW, Machado Filho CD. Histamine, histamine receptors and antihistamines: New concepts. An Bras Dermatol 2010;85(2):195-210.

2. Nerdy, Putra ED, Tjahjono DH. Development and validation of high performance liquid chromatography mass spectrometry method for determination of rifampicin, isoniazid and pyrazinamide from tablet preparation. Int J PharmTech Res 2014;6(5):1647-64.

3. Moffat AC, Osselton MD, Widdop B. Clarke's Analysis of Drug and Poisons. $3^{\text {rd }}$ ed. London: Pharmaceutical Press; 2004.
4. Syed MR, Hashmi S, Naik JB. Ultraviolet spectrophotometric method development and validation for determination of paroxetine hydrochloride in pharmaceutical dosage form. Int J Pharm Pharm Sci 2010;2(2):43-5.

5. Pourghazi K, Khoshhesab XM, Golpayeganizadeh A, Shapouri MR, Afrouzi H. Spectrophotometric determination of cetirizine and montelukast in prepared formulations. Int $\mathrm{J}$ Pharm Pharm Sci 2011;3(2):128-30.

6. Yadav N, Goyal A. Validated spectrophotometric method for determination of vilazodone hydrochloride in pharmaceutical dosage form. Int J Curr Pharm Res 2017;9(1):132-5.

7. Dibbern HW, Müller RM, Wirbitzki E. Ultraviolet and Infrared Spectra. Germany: Cantor Verlag Aulendorf; 2002.

8. Wulandari L, Yuwono M, Indrayanto G. Densitometric determination of mebhydrolin napadisylate in tablets. J Planar Chromatogr 2012;25(1):60-4

9. Wulandari L. Determination and validation of mebhydroline napadisylate in tablets by high performance liquid chromatography. Indones J Chem 2008;8(3):377-9.

10. Zagorodny CL, Vasyuk SA. Development spectrophotometric method of determination mebhydrolin in dosage forms. Aktual Pitann Ã Farm Med Nauki Prakt 2015;4(17):33-8

11. Rohman A, Gandjar IG. Pharmaceutical Chemistry Analysis. $1^{\text {st }}$ ed. Yogyakarta: Pustaka Pelajar; 2007.

12. Épshtein NA. Validation of high performance liquid chromatography techniques for pharmaceutical analysis. Pharm Chem J 2004;38(4):212-28.

13. Indonesia Health Ministry. Indonesia Pharmacopoeia. $5^{\text {th }}$ ed. Jakarta: Indonesia Health Ministry; 2014.

14. Pavia DL, Lampman GM, Kriz GS. Introduction to Spectroscopy. Philadelphia: Saunders Golden Sunburst Series; 1979.

15. Miller JM. Chromatography Concepts and Contrast. $2^{\text {nd }}$ ed. New York: Wiley Interscience; 2005.

16. Harmita. Method Validation Implementation Guidelines and Calculations. Jakarta: Department of Pharmacy, Faculty of Mathematics and Natural Sciences, University of Indonesia; 2004.

17. Rohman A. Chromatography for Drug Analysis. $1^{\text {st }}$ ed. Yogyakarta: Graha Ilmu; 2009.

18. Indonesia Health Ministry. Indonesia Pharmacopoeia. $4^{\text {th }}$ ed. Jakarta: Indonesia Health Ministry; 1995.

19. Ermer J. Method Validation in Pharmaceutical Analysis. Weinheim: Wiley Verlag; 2005. 